\title{
Production and Characterization of an Eco-Friendly Oil Based Mud from Synthetic Bio-lubricant Derived from Chrysophyllum Albidum Seed Oil
}

\section{IGBAFE Sylvia ${ }^{1,}$, AZUOKWU Augustine A. ${ }^{2, b^{*}}$ and IGBAFE Anselm I. ${ }^{3, c}$}

\author{
${ }^{1}$ Department of Petroleum Engineering, Covenant University, Ota, Ogun State, Nigeria \\ ${ }^{2}$ Department of Chemical and Petroleum Engineering, Igbinedion University, Okada, Edo State, Nigeria \\ ${ }^{3}$ Department of Chemical and Petroleum Engineering, Afe Babalola University, Ado-Ekiti, Ekiti State, Nigeria

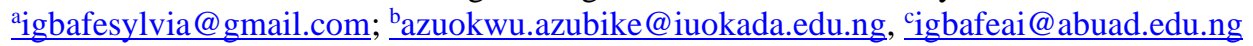 \\ *: bazuokwu.azubike@iuokada.edu.ng
}

Received: $19^{\text {th }}$ April 2021

Received: $19^{\text {th }}$ April 2021

Published: $2^{\text {nd }}$ September

https://doi.org/10/47545/ertj.2021.6.2.083

\begin{abstract}
Sequel to the environmental problems of the none biodegradable nature of the conventional oil-based drilling fluids, it is imperative and urgent for environmental sustainability and for the development of eco-friendly products, that use of petroleum diesel oil as the continuous phase of drilling mud warrant urgent reconsideration. Towards the search to provide a better alternative to petroleum diesel oil as a base oil for drilling mud, vegetable oil from the inedible seeds of the African star apple fruits, was examined In this study, an oil-based drilling mud (OBM) with biodegradable qualities for sustainable environmental applications was developed and characterized. The OBM was produced with chrysophyllum albidum (African star apple) oil methyl ester bio-lubricant to replace petroleum diesel as the continuous phase of the mud. The chrysophyllum albidum oil methyl ester was synthesized from fatty acid methyl ester obtained through transesterification process of none edible oils extracted from chrysophyllum albidum seeds. Tests of physiochemical and rheological properties were carried out on mud samples of chrysophyllum albidum oil biolube-based mud (CAOBBM) and petroleum diesel oil-based mud (PDOBM) to characterise the fluids for performance evaluation and environmental consequences. The findings indicated that CAOBBM was lower in density and less acidic than PDOBM, at barite content of $20 \mathrm{~g}$. Also, CAOBBM had lower viscosity which implies less resistance to flow and lower pressure losses. The low oil to water ratio from the filtration loss test, revealed that CAOBBM is more viable to low fluid loss and consequently enhances wellbore stability and less oil retained on drilled cuttings. Similarly, toxicity test confirmed CAOBBM to be more appropriate and less detrimental to the environment compared to PDOBM. Summarily chrysophyllum albidum oil biolube based muds stands safer and more eco-friendly for a sustainable environment than petroleum diesel oil-based muds.
\end{abstract}

Keywords: Oil-based drilling muds, bio-lubricant, chrysophyllum albidum oil eco-friendly.

\section{INTRODUCTION}

The need to drill a usable hole with minimal environment impact and a low-cost imprint as a dream long held by the drilling industries and operators. A key component of the oil well drilling operation known as '-the blood of the drilling process-', is the drilling fluid. It is the foundation which makes a drilling operation either to succeed or fail [1]. The success of drilling program is hinged on the performance of the drilling fluids in the transport the drilled solids from the bottom of the hole to the surface; suspension of the drilled solids and weighting materials when the mud is under static condition; providing a thin impermeable cake to seal pore and other openings in the formation and there by restricting the movement of fluids; containing formation pressure; supporting the weight of casing and drill string; transmitting hydraulic horse power to the bit; aiding in evaluation of the formation; removal of cuttings from the wellbore; prevention of formation fluids flowing into the well-bore; maintaining well-bore stability; cooling and lubricating the bit [1,2]. The fluid is formulated from three principal materials: base liquid - oil, fresh water, or salt water; active solids - clays and polymers; inert solids - such as barite; and other reactive and inert materials as additives for improved fluids performance. The performance of any drilling fluid depends on the rheological properties. A good lubricant for drilling fluids exhibits relatively high viscosity, high lubricating film strength, low corrosively, low pour point, low flammability, high solubility, high thermal and oxidative stability and non-toxic. In addition, higher electrical stability helps to maintain a strong emulsifying strength as the reservoir temperature increases. This is because increase in temperature increases the ionic activity of an electrolyte and the solubility of salts which alters the attractive and repulsive forces among particles as well 
as the dispersion and flocculation, consequently affect mud emulsion stability $[3,4]$. In addition, the environmental impact management of waste drilling forms additional cost implications on the overall budget for the drilling operation.

Oil-based mud (OBM) uses oil as the continuous phase. It is widely used in wells that are prone to drilling problems such as formation damage. It also provides good stability in shale zones and well, good lubricity efficiency for faster rate of drill pipe penetration, thermal stability, lowers rate of corrosion, reduce risk of stuck pipe and low formation damage, lower friction and torque values [5]. In recent times, some vegetable oils have been assured to be adequate oils for the production of sustainable environmentally friendly oil-based drilling mud (OBM) from their renewability to possessing high biodegradability, high lubricity and very less toxicity to the ecosystem [6,7]. Bio-lubricants also referred to as polyol esters are the synthetic biological lubricants from vegetable oils having excellent qualities as feedstock for the eco-friendly OBM production [8].

Bio-lubricants are synthetic esters produced from transesterified oils extracted from seeds and flowers of varieties of plants which include palm kernel oil, canola oil, soybean, castor oil, moringa oil, rapeseed, sunflower, coconut oils, neem seed, karanja, rubber seed, jatropha and African star apple seed [8-11]. Some physiochemical properties of polyols esters of the light brown coloured chrysophyllum albidum oil and other vegetable oils are presented elsewhere [8]. Bio-lubricants formulated OBM are lower in cost of production being that vegetable oils are renewable, easily sourced and disposed with no environmental consequence [12]. Thus, the study was aimed at production and characterization of oil-based mud from bio-lubricant derived from the esterified oils from chrysophyllum albidum seed. Chrysophyllum albidum (commonly known as white star apple or African star apple) is a large berry forest fruit tree containing 4-5 flattened seeds found throughout tropical Africa significantly in western, eastern and southern parts of Nigeria [13]. The study was intended to contribute towards the Nigerian local content initiative (NLCI) and to reduce the effects of environmental impact of waste generated from drilling operations.

\section{METHODOLOGY}

\subsection{Synthesis of the Chrysophyllum albidum Bio-lubricant}

Materials: The materials used in the study included seeds of African star apple, n-hexane 98\%, methanol 99.8\% and potassium hydroxide pellet $95 \%$ of analytical grade BDH chemicals, trimethylolpropane, sodium methoxide, Soxhlet apparatus, $0-100^{\circ} \mathrm{C}$ thermometer, model N-1110S rotary evaporator (Rikakikai, Tokyo), separating funnels, pycnometer.

Chrysophyllum albidum bio-lubricant synthesis: In this study, bio-lubricant of chrysophyllum albidum oil also referred as chrysophyllum albidum oil biolube was synthesised from chrysophyllum albidum oil biodiesel, technically known as chrysophyllum albidum oil fatty acid methyl esters which was obtained from the tranesterification of the fatty acids of the oil extracted from chrysophyllum albidum seeds in line with the procedures described elsewhere [7, 8, 14-16].

\subsection{Mud Formulation Procedure}

Chrysophyllum albidum oil biolube-based drilling mud preparation: Chrysophyllum albidum oil biolubebased mud (CAOBBM) was formulated according to the American Petroleum Institute (API) standard; $22.5 \mathrm{~g}$ of bentonite was dissolved in $350 \mathrm{ml}$ of fluid comprising of $117 \mathrm{ml}$ of chrysophyllum albidum oil biolube and $233 \mathrm{ml}$ of water. The mixture was agitated for 5-10 minutes using an electronic mixer followed by the addition of $2 \mathrm{~g}$ of sodium hydroxide and $1.5 \mathrm{~g}$ of PAC. When a clear homogeneous mixture was achieved, $8 \mathrm{ml}$ of emulsifier, $6 \mathrm{ml}$ of dispersant and $10 \mathrm{~g}$ of barite subsequently added consecutively at 5 minutes interval and allowed to mix until a homogeneous liquid was attained. The prepared fluids were subjected to $24 \mathrm{~h}$ aging to ensure whole hydration before analyses [12, 17-19].

Petroleum diesel oil-based drilling mud preparation: The procedure adopted for the preparation of chrysophyllum albidum oil biolube-based mud preparation was also applied to petroleum diesel oil for the production of petroleum diesel oil-based mud (PDOBM).

\subsection{Drilling fluid property characterisation}

The characteristics of the chrysophyllum albidum oil biolube-based mud (CAOBBM) and petroleum diesel oil-based mud (PDOBM) produced, were evaluated using their properties determined. The properties which were to provide indications on the mud potential performance, were determined with standard procedures. They included $\mathrm{pH}$, density, rheological, sand content and mud toxicity. The ASTM D4380 standard procedure for determination of mud density and specific gravity were adopted, a calibrated mud balance was used for the 
process. Physical appearances of colour were based on ASTM D2622 [16,20]. A pH meter was adopted to ascertain the $\mathrm{pH}$ of the mud samples and a Brookfield Ultra DVIII programmable rheometer was used to test the prepared mud viscosity. Following the Brookfield Digital Rheometer Model DV-III Operating Instructions Manual No. M98-211-A0701: the rheometer was assembled and leveled, it was then autozeroed, the spindle number was entered using the SELECT SPINDLE key, the spindle was introduced into the mud sample and attached to the coupling nut, the speed of rotation was entered using the number pad and ENTER key, \% torque and viscosity were then recorded. Fluid loss determination was done using the standard API filter press by applying differential pressure on a dead weight filter press with filtrates recorded at intervals of 30 minutes $[12,18]$. Drilling fluid toxicity test experiment was carried out on growing maize plant seedling to examine the effects of both mud types contamination interference on the growth and ascertain the harm to soil and the microorganisms. Maize seedlings were planted in soil contaminated of the two types of prepared mud samples and a control soil containing no mud for 30 days. Growth rates was measured on effective concentration $50 \%$ $\left(\mathrm{EC}_{50}\right)$ as described elsewhere [21]. The $\mathrm{EC}_{50}$ is the concentration of the toxic contaminant present in the soil at which half the maximum expected growth response is realized [21].

\section{RESULTS AND DISCUSSION}

\subsection{Physiochemical property analyses}

Table 1, presents physiochemical properties of two OBM types formulated from the chrysophyllum albidum oil biolube and petroleum diesel oil. The colour of the CAOBBM was grey white while that of the PDOBM was creamy white, hence no significant discrepancy. The whitish coloration is attributed to the large amount of white coloured barite constituent of both mud types.

Table 1: Physicochemical properties of different OBM measured and from literature

\begin{tabular}{|c|c|c|c|c|c|}
\hline Parameters/mud & $\mathbf{p H}$ & $\begin{array}{c}\text { Density, } \\
\text { Ib/gal } \\
\text { @ } 25^{\circ} \mathrm{C}\end{array}$ & $\begin{array}{l}\text { Specific } \\
\text { gravity } \\
@ 15^{\circ} \mathrm{C}\end{array}$ & $\begin{array}{c}{ }^{\circ} \mathrm{API} \\
\text { gravity } \\
\text { @ } 15^{\circ} \mathrm{C}\end{array}$ & $\begin{array}{c}\text { Electrical } \\
\text { stability } \\
\text { (V) }\end{array}$ \\
\hline Petroleum diesel oil (This Study) & 8 & 8.53 & 0.853 & 34.4 & 210 \\
\hline aPetroleum diesel oil & ND & 8.26 & 0.826 & 39.8 & ND \\
\hline${ }^{b}$ Petroleum diesel oil & ND & 8.1 & 0.81 & 43.2 & ND \\
\hline${ }^{c}$ Petroleum diesel oil & ND & 8.26 & 0.826 & 39.8 & ND \\
\hline Chrysophyllum albidum biolube (This Study) & 8.1 & 8.77 & 0.877 & 29.9 & 210 \\
\hline${ }^{\mathrm{a}}$ Gamelina oil & 11.26 & 8.32 & 0.832 & 38.6 & ND \\
\hline bSoybean oil & 9 & 10.5 & 1.05 & 3.3 & ND \\
\hline${ }^{\mathrm{c}}$ Algae oil & 9 & 7.81 & 0.781 & 49.7 & ND \\
\hline${ }^{\mathrm{c}}$ Jatropha oil & 8.5 & 8.32 & 0.832 & 38.6 & ND \\
\hline${ }^{\mathrm{c}}$ Moringa oil & 9 & 8.3 & 0.83 & 38.98 & ND \\
\hline${ }^{\mathrm{c} C a n o l a}$ oil & ND & 8.47 & 0.847 & 35.6 & ND \\
\hline${ }^{\mathrm{d}}$ Groundnut oil & ND & 7.9 & 0.79 & 47.6 & ND \\
\hline
\end{tabular}

a $[22] ;{ }^{\mathrm{b}}[17] ;{ }^{\mathrm{c}}[12] ;{ }^{\mathrm{d}}$ [5]; ND: Not determined

The $\mathrm{pH}$ is a vital indicator of the mud quality. The $\mathrm{pH}$ of the CAOBBM and PDOBM were 8.2 and 8.1 respectively. Though mildly were alkaline, both mud types agree with the observations that drilling muds are alkaline such that values between 8.5 and 9.5 produces mud with the best hole stability, control properties and protect pipe and casing from acidic fluid corrosion $[17,23]$. The $\mathrm{pH}$ values of the samples are also comparable with other bio-OBM, however for fluids with values higher than 10, drilling in shale zone is problematic $[5,12,17,22]$. Similar to $\mathrm{pH}$ observations, the density of a drilling fluid another important indicator of the mud quality. The drilling fluid should be designed to provide high density [24]. The densities of CAOBBM and PDOBM oil-based muds were 8.77 and 8.53 ppg respectively. Though weighting materials added during mud formulations contribute to the mud density. The higher the density of CAOBBM, the better its aid to maintain wellbore hydrostatic pressure, prevents influx of other fluids as well as lost circulation in the wellbore and 
enhanced cuttings carrying capacity [12,22]. With density, the CAOBBM appears more encouraging over PDOBM. Also, similar characteristics are deducible from the specific and ${ }^{\circ} \mathrm{API}$ gravities. Drilling fluid with higher electrical stability has the tendency to maintain a strong emulsifying strength as the reservoir temperature increases. In this study, the electrical stability at ambient temperature of CAOBBM and PDOBM oil-based muds were equal at $210 \mathrm{~V}$. Thus, there was no effect on the electrical stability property with regard to the oil type of the mud.

\subsection{Rheological property analyses}

The rheological properties consisting of plastic viscosity, apparent viscosity, gel strength and yield point of OBM formulated from chrysophyllum albidum oil biolube and petroleum diesel oil together with published values in literatures are contained in the Table 2.

On mud viscosity, the CAOBBM appear more viscous than PDOBM due to its higher plastic and apparent viscosities. Though not a large difference, the high plastic and apparent viscosities, implies that the resistance to flow is greater CAOBBM with than PDOBM. However, CAOBBM appear more viscous than some of the plant seed oils notably Gamelina oil, Jatropha oil and Groundnut oil. Drilling fluid are known to possess close similar rheological behaviour however, the presence of contaminants affects the flow behaviour and builds up shear stress leading to a yield point. When shear stress exceeds the yield point, it is influenced by the fluid plastic viscosity resulting in reduced friction during flow in the drill pipes [22]. Therefore, since PDOBM had a lower viscosity, it will be more efficiently with less resistance to flow, less circulation pressure and reduced frictional damages in pipes. It consequently would result to lower pumping costs together with reduced circulation loss probabilities. However, the efficiency of PDOBM will not be different from that of the CAOBBM because there is no significant difference in their plastic and apparent viscosities.

On gel strength there is no significant difference between CAOBMM and PDOBM. Both muds have a good gel structure, are capable of suspending drilled cuttings and weighting material when mud circulation is stopped.

Similar to the viscosities and the gel strengths, the yield points of both muds prepared had very close values (14 $\mathrm{Ib} f / 100 \mathrm{ft}^{2}$ and $13 \mathrm{Ib} f / 100 f t^{2}$ for PDOBM and CAOBMM respectively); hence there is no significant difference between both muds. The yield point results showed that both CAOBMM and PDOBM are capable of lifting or removing the cuttings out of the wells. Although, PDOBM with slightly higher yield point will carry cutting slightly better than the CAOBMM; however, which could lead to slightly higher-pressure losses for the PDOBM.

The rheological results stated above strongly infer that CAOBMM can be used in place of PDOBM.

Table 2: Rheological properties of different OBM measured and from literature

\begin{tabular}{|c|c|c|c|c|c|}
\hline Parameters/Mud & $\begin{array}{l}\text { Plastics } \\
\text { viscosity } \\
\text { (cp) }\end{array}$ & $\begin{array}{l}\text { Apparent } \\
\text { viscosity } \\
\text { (cp) }\end{array}$ & $\begin{array}{l}\text { Gel strength } \\
\text { @ } 10 \mathrm{~s} \\
\left(\mathrm{Ib} f / 100 f t^{2}\right)\end{array}$ & $\begin{array}{l}\text { @ } 10 \text { mins } \\
\left(\mathrm{Ib} f / 100 f t^{2}\right)\end{array}$ & $\begin{array}{l}\text { Yield } \\
\text { point } \\
\left(\mathrm{Ib} f / 100 f t^{2}\right)\end{array}$ \\
\hline Petroleum diesel oil (This Study) & 15 & 19 & 3 & 5 & 14 \\
\hline${ }^{\text {aPetroleum diesel oil }}$ & 15 & 92.5 & 50 & 51 & 92.5 \\
\hline betroleum diesel oil & 14 & 21 & 5 & 6 & 14 \\
\hline 'Petroleum diesel oil & 15 & 92.5 & 50 & 51 & ND \\
\hline $\begin{array}{l}\text { Chrysophyllum albidum biolube (This } \\
\text { Study) }\end{array}$ & 18 & 24.5 & 5 & 7 & 13 \\
\hline a Gamelina oil & 21 & 77 & 54 & 55 & 77 \\
\hline bSoybean oil & 15 & 23 & 7 & 9 & 16 \\
\hline${ }^{\mathrm{c} A l g a e}$ oil & 8 & 61 & 52 & 43 & ND \\
\hline${ }^{\mathrm{c}}$ Jatropha oil & 21 & 77 & 54 & 55 & ND \\
\hline${ }^{\mathrm{d}}$ Jatropha oil & 28.3 & 54.2 & 8 & 10 & ND \\
\hline cMoringa oil & 11 & 84.5 & 52 & 53 & ND \\
\hline${ }^{\mathrm{c} C a n o l a ~ o i l ~}$ & 8 & 64 & 60 & 72 & ND \\
\hline${ }^{\mathrm{d}}$ Groundnut oil & 35.67 & 48.7 & 5 & 7 & ND \\
\hline
\end{tabular}

${ }^{\mathrm{a}}[22] ;{ }^{\mathrm{b}}[17] ;{ }^{\mathrm{c}}[12] ;{ }^{\mathrm{d}}[5] ;$ ND: Not determined 


\subsection{Filtration loss property}

Table 3 presents the mud filtration properties consisting of mud cake, total fluid volume, oil volume and water loss volume for CAOBBM and PDOBM together with published values in literatures. The CAOBBM showed a cake with lower thickness thus greater ability to increase its weight as well as collected less filtrate volumes of oil and water [12]. The PDOBM had higher filtration loss rate with higher filtrate volumes which implied that its cake was more porous. This may be attributed to PDOBM unsuccessful attainment of a stable oil and water emulsion compared to the CAOBMM achieving stronger emulsion between the oil and water [12]. The low oil to water ratio is indicative that CAOBBM is adequate to low fluid loss an enhanced wellbore stability and less oil retained on drilled cuttings. Therefore, the CAOBBM possessed preferred filtration properties as against PDOBM on the basis of total fluid volume, whereas the latter is preferred on cake thickness.

Table 3: Mud filtration properties of different OBM measured and from literature

\begin{tabular}{|c|c|c|c|c|}
\hline Parameters/mud & $\begin{array}{c}\text { Total fluid } \\
\text { volume (ml) }\end{array}$ & $\begin{array}{l}\text { Oil volume } \\
\qquad(\mathrm{ml})\end{array}$ & $\begin{array}{l}\text { Water } \\
\text { loss }(\mathrm{ml})\end{array}$ & $\begin{array}{l}\text { Mud cake } \\
\quad(\mathrm{mm})\end{array}$ \\
\hline Petroleum diesel oil (This Study) & 6.6 & 2.3 & 4.4 & 1.7 \\
\hline aPetroleum diesel oil & 6.9 & 2.3 & 4.6 & 1 \\
\hline${ }^{b}$ Petroleum diesel oil & 30 & 11 & 19 & 3 \\
\hline${ }^{\mathrm{c}}$ Petroleum diesel oil & 6.9 & 2.3 & 4.6 & 1 \\
\hline $\begin{array}{l}\text { Chrysophyllum albidum biolube (This } \\
\text { Study) }\end{array}$ & 6.3 & 2 & 4.3 & 1.4 \\
\hline a⿳amelina oil & 6.3 & 2.1 & 4.2 & 0.8 \\
\hline${ }^{\mathrm{b}}$ Soybean oil & 35 & 15 & 20 & 2.5 \\
\hline${ }^{\mathrm{c} A l g a e}$ oil & 6.2 & 1.1 & 5.1 & 0.9 \\
\hline${ }^{\mathrm{c} J a t r o p h a ~ o i l ~}$ & 6.3 & 1.1 & 4.2 & 0.8 \\
\hline${ }^{\mathrm{c}}$ Moringa oil & 7.2 & 2.5 & 4.7 & 0.9 \\
\hline${ }^{\mathrm{c} C a n o l a ~ o i l ~}$ & 6 & 1 & 4.3 & 0.78 \\
\hline
\end{tabular}

\subsection{Cuttings carrying capacity index}

The cuttings carrying capacity indices of the CAOBBM and PDOBM and others from literature are displayed in Table 4. The capability to regulate the movement of drilled from the wellbore depends on some rheological properties. The cuttings carrying capacity index is a measure of the ability of drilling fluid to conduct drilled cuttings up the drill string. The higher a mud cutting carrying capacity index, the better its ability to transport solid out of the drilled hole. Thus, with a higher cutting carrying capacity index, COABBM has higher capability for uptake of drilled cuttings compared to PDOBM.

Table 4: Cutting carrying capacity index for OBMs determined and from literature

\begin{tabular}{lc}
\hline Parameters/mud & $\begin{array}{c}\text { Cutting carrying } \\
\text { capacity index }\end{array}$ \\
\hline Petroleum diesel oil (This Study) & 15.2 \\
aPetroleum diesel oil & 15.901 \\
Chrysophyllum albidum biolube (This Study) & 18.64 \\
a Jatropha oil & 19.067 \\
aCanola oil & 17.846 \\
\hline${ }^{a}$ [17].
\end{tabular}

\subsection{Specific Application of the CAOBBM}

The CAOBBM and PDOBM and others from literature are displayed in Table 4. The capability to regulate the movement of drilled from the wellbore depends on some rheological properties. The cuttings carrying capacity index is a measure of the ability of drilling fluid to conduct drilled cuttings up the drill string. The higher a mud cutting carrying capacity index, the better its ability to transport solid out of the drilled hole. Thus, with a higher 
cutting carrying capacity index, COABBM has higher capability for uptake of drilled cuttings compared to PDOBM.

\subsection{Environmental impact}

The growth rate (\% per day) responses against time (days) of the plant is shown in Figure 1. The soil contaminated with mud of petroleum diesel oil was designated SPDOM while that of chrysophyllum albidum methyl ester biolubricant was designated SCAOMEM and thirdly the uncontaminated soil sample which represents any fertile soil for comparative purposes was designated SCONTROL. The number of days corresponds with the half maximum effective concentration $\left(\mathrm{EC}_{50}\right)$ of antagonistic contaminants in the soil. The plant growth rate was gentle and consistent but varied slightly in amount within the first 7 days, thereafter the effects of the contaminants became noticed. In the case of SPDOM, the deterioration rate was rapid and acute resulting to total collapse of the plant in less than 10 days of exposure time. On the other hand, the plants in the SCOAMEM progress at a moderately slow response rate up to the 28 day and thereafter a relapse was noticed. This implies that both soil types ultimately require microbial or mineral beneficiation over time. In similar studies elsewhere [21], the $\mathrm{EC}_{50}$ for SCAOMEM was determined as $42.3 \%$, while that of the SPDO was undetermined because the growth response abruptly declined to zero and there was no more growth response up to one half the expected maximum before the 30-day duration. Although, despite a reduced percentage growth rate observed in SCAOMEM compared to SCONTROL, the plants exposed to bio-lubricant formulated mud contaminated soil survived and grew continuously throughout the test duration. This implies that muds of chrysophyllum albidum oil bio-lubricant are less toxic and detrimental to environment compared to mud of petroleum diesel oil. Bio lubricant oils are safer and eco-friendlier than petroleum-based fluids. The biodegradation and bioaccumulation of microbes depend on the chemistry of the base fluids. These can also be enhanced with biostimulating agents to increase the intrinsic biodegradation potentials of the microbial populations.

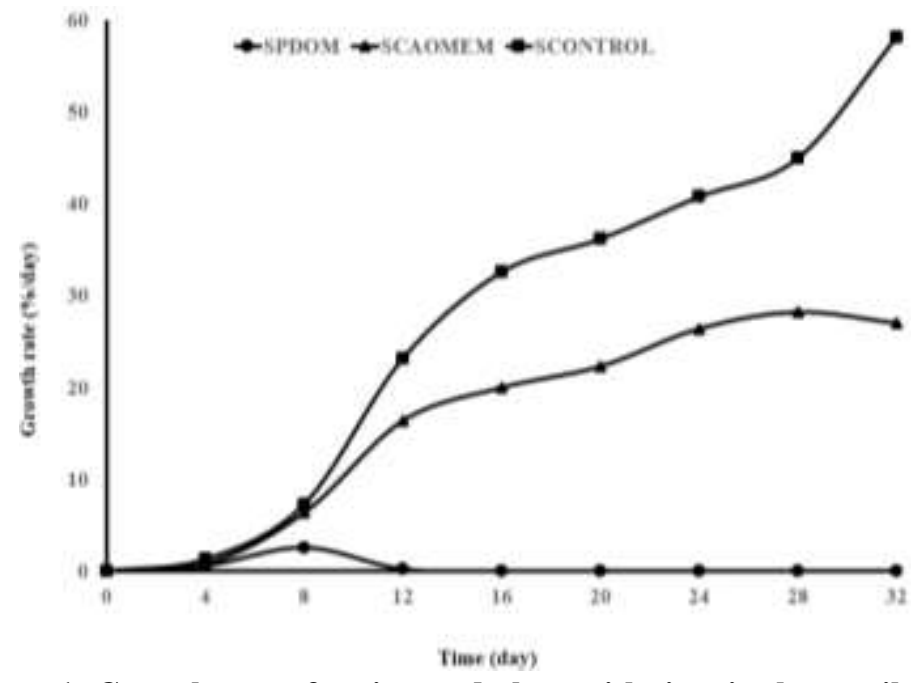

Figure. 1: Growth rate of maize seed plant with time in three soil types

\section{CONCLUSION}

In this study, OBMs of chrysophyllum albidum oil bio-lubricant and petroleum diesel oil were produced. The OBM of chrysophyllum albidum oil bio-lubricant indicated a higher average $\mathrm{pH}$ which places it more alkaline thus would be preferred for protection of pipe and casing from acidic fluid corrosion and lower density hence improved potentials to maintain wellbore hydrostatic pressure, prevents influx of other fluids as well as lost circulation in the wellbore and enhanced cuttings carrying capacity. The OBM of petroleum diesel oil was lower in viscosity which implies less resistance to flow and lower pressure losses and thus more easily to pump; however, there is no significant difference between its plastic and apparent viscosities and those of the OBM of chrysophyllum albidum oil bio-lubricant. Both muds have a good gel structure, are capable of suspending drilled cuttings and weighting material when mud circulation is stopped. The yield point results showed that both muds are capable of lifting cuttings out of the wells. In addition, outstandingly the oil to water ratio was lower making chrysophyllum albidum oil bio-lubricant OBM more viable to less fluid loss and better capability to enhance wellbore stability and less oil retained on drilled cuttings. Based on toxicity test outcomes, OBMs of chrysophyllum albidum oil bio-lubricant are safer and eco-friendlier for drilling operations for a sustainable environmental than that of petroleum diesel oil. They can be enhanced for extended biodegradation potentials with biostimulating agents to increase the indigenous microbial populations. 


\section{ACKNOWLEDGEMENT}

Authors wish to acknowledge Mr. D. Ewere, for his assistance during experimental laboratory investigations.

\section{REFERENCES}

[1]. A. Saxena, A. K. Pathak, K. Ojha. Optimization of characteristic properties of foam- based drilling fluids, Brazilian Journal of Petroleum and Gas, 2014, 8(2), 57-71.

[2]. H. A. Ellis. Drilling Engineering Handbook, International Human Resources Development Corporation, Lancaster, 1983.

[3]. D. Kania, R. Yunus, R. Omar, S. Abdul Rashid, J. Mohamad. A review of bio-lubricants in drilling fluids, Journal of Petroleum Science Engineering, 2015, 135, 177-184.

[4]. O. A. Adekomaya. Experimental analysis of the effect of magnesium saltwater influx on the behaviour of drilling fluids, Journal of Petrol Exploration and Production $\quad$ Technology, 2013, 3, 61-67.

[5]. C. Y. Onuh, A. Dosunmu, P. A. L. Anawe, V. Efeovbokhan, A. Adebisi. Transesterification of non-edible vegetable oil for lubricant applications in water-based mud: a review, International Journal of Applied Engineering Research, 2017, 12(18), 7397-7401.

[6]. K. J. Amit, S. Amit. Capability of bio-lubricants as alternative lubricant in maintenance applications, International Journal of Current Engineering and 3(1), 180-183.

[7]. K. H. Ebtisam, M. S. Elmelawy, S. A. Khalil, N. M. Elbasuny. Manufacturing of environment friendly bio-lubricants from vegetable oils, Egyptian Journal of Petroleum,

[8]. S. Igbafe, A. A. Azuokwu, A. I. Igbafe. Production and characterization of chrysophyllum albidum seed oil derived bio-lubricant for the formulation of oil-based drilling mud, IOSR Journal of Biotechnology and Biochemistry, 2020, 6(2), 27-32.

[9]. H. Wagner, R. Luther, T. Mang, Lubricant base fluids based on renewable raw materials: $\quad$ Their catalytic manufacture and modification, Applied Catalysis A-General, 2001, 221, 429-442.

[10]. A. M. Ashraful, H. H. Masjuki, M. A. Kalam, I. M. Rizwanul Fattah, S. Imtenan, S. A. Shahir, H. M. Mobarak. Production and comparison of fuel properties, engine performance and emission characteristics of biodiesel from various non-edible vegetable oils: a review, Energy Conversion and Management, 2014, 80, 202-228.

[11]. S. E. Onoji, S. E. Iyuke, A. I. Igbafe, M. O. Daramola. Transesterification of rubber seed oil to biodiesel over a calcined waste rubber seed shell catalyst: Modeling and optimization of process variables, Energy and Fuels, 2017, 31(6), 6109-6119.

[12]. T. El-Fakharany, A. A. Geliel, H. Salhin. Formulating environmentally friendly oil- base mud using soybean oil, International Advanced Research Journal in Science, Engineering and Technology, 2017, 4(7), 57-61.

[13]. J. A. Ugwu, V. C. Umeh. Assessment of African star apple fruit damage due to insect pests in Ibadan southwest Nigeria, Research Journal of Forestry, 2015, 9, 87-92.

[14]. M. M. K. Bhuiya, M. G. Rasul, M. M. K. Khan, N. Ashwath, A. K. Azad, M. Mofijur. Optimization of oil extraction process from Australian native beauty leaf seed (Calophyllum inophyllum), Energy Procedia, 2015, 75, 56-61.

[15]. O. O. Awolu, S. K. Layokun. Optimization of two-step transesterification production of biodiesel from neem (Azadirachta indica) oil. International Journal of Energy and Environment Engineering, 2013, 4 (1), 39.

[16]. I. N. Dibal, P. C. Okonkwo. Production of bio-lubricant from castor oil, Society of Petroleum Engineers, Nigeria Annual International Conference and Exhibition, SPE- 189183-MS, 31 July 2 August, Lagos, Nigeria, 2017.

[17]. A. Fadairo, O. Falode, C. Ako, A. Adeyemi, A. Ameloko. Novel formulation of environmentally friendly oil based drilling mud, In: New technologies in the oil and gas industry, Edited by Jorges Salgado Gomes, In: Tech publication, Croatia, 2012, Chapter 3, 49-80.

[18]. P. A. L. Anawe, V. E. Efeovbokhan, A. A. Ayoola, O. Akpanobong. Investigating alternatives to diesel in oil based drilling formulations used in the oil industry, Journal of Environment and Earth Science, 2014, 4(14), 70-77.

[19]. S. Igbafe. Production and characterization of a synthetic oil based mud from chrysophyllum albidum seed oil bio-lubricant, B.Eng. Research Project, Igbinedion University, Okada, Edo State, Nigeria, Unpublished, 2019, 1-75. 
[20]. ASTM. American Society for Testing and Materials: Annual Books of ASTM standards: petroleum products, lubricants and fossil fuels, Vol. 5:1, Sect. 5. American Society for Testing and Materials, Philadelphia (USA), 1995.

[21]. J. Tang, M. Wang, F. Wang, Q. Sun, Q. Zhou. Eco-toxicity of petroleum hydrocarbon contaminated soil, Journal of Environmental Science, 2011, 23(5), 845-

[22]. M. N. Nwanekezie, S. E. Ogbeide. Formulation of oil-based drilling fluids (muds) from plant seed oil (Gamelina arborea seed oil). Chemical and Process $\quad$ Engineering Research, 2017, 50, 35-46.

[23]. Baker Hughes. Drilling Fluids Reference Manual Revised, 2006.

[24]. S. Elkatatny, Enhancing the stability of invert emulsion drilling fluid for drilling in high-temperature conditions, Energies, 2018, 11, 1-15

high-pressure 